\title{
Pembaharuan Hukum Acara Pidana Berwawasan Hak Asasi Manusia dalạm Perspektif Teori Konstrusionisme
}

\author{
Arief Setiawan
}

\begin{abstract}
$\therefore \quad$ Abstract
In theoretic perspective for constructionism, each of the parties involved in the process on criminal court is suitable with the position and the role of each the process for criminal court itself would make ideas to decide for their own objectives and to act as according to the objectives assigned deliberately. In doing this action, then they give the meaning to their action or behaviour and as well as they will give the reasons about the action to carry out. The consequence is the raising on different meaning. These writings describe about the innovation of law on criminal procedure in the frame of Human Right in the theoretical perspective of constructionism.
\end{abstract}

\section{Pendahuluan}

Pelaksanaan hukum acara pidana di Indonesia yang sewenang-wenang dan melanggar hak asasi manusia (HAM) terhadap mereka yang diduga sebagai pelaku perbuatan pidana (tersangka atau terdakwa) telah tercatat dalam sejarah. Ada beberapa laporan mengenai hal itu. Bentuk-bentuk pelanggaran HAM seperti pemaksaan fisik maupun psikhis sering dilakukan oleh aparat penegak hukum pidana di tingkat pemeriksaan pendahuluan (penyelidikan/ penyidikan) terhadap tersangka atau bahkan saksi sekalipun. Salah satu tujuan pemaksaan tersebut adalah untuk memperoleh keterangan atau pengakuan yang sesuai dengan kebutuhan petugas pemeriksa.

Jenis pelanggaran yang lain yang juga sering dilakukan oleh aparat penegak hukum pidana di tingkat pemeriksaan pendahuluan terhadap tersangka atau pihak lainnya adalah yang menyangkut kebebasan bergerak dan hak kepemilikan. Sering terjadi adanya tindakan penggeledahan rumah/badan, dan penyitaan yang tidak sesuai dengan ketentuan prosedural untuk melakukan tindakan tersebut. Tidak mengherankan apabila pelaksanaan upaya paksa seperti penangkapan, penahanan, penggeledahan badan, 
penggeledahan rumah, dan penyitaan sering dipersoalkan keabsahannya oieh pihak tersangka atau terdakwa. ${ }^{1}$

Dari pengamatan terhadap kasus-kasus pelanggaran HAM dalam proses peradilan pidana, setidak-tidaknya ada dua masalah yang perlu mendapatkan perhatian, yaitu: Pertama apakah aparat penegak hukum pidana telah melakukan kewajiban-kewajiban bagi penegak hukum. Dari segi etika deontologis, terdapat tuntutan kepada aparat penegak hukum untuk menjalankan seluruh kewajibannya dalam rangka memberikan hakhak yuridis ${ }^{2}$ yang semestinya mereka berikan kepada tersangka/terdakwa, atau saksi. Kedua, dari segi peraturan hukum acara pidana yang berlaku. Hal yang dipersoalkan adalah apakah hukum acara pidana yang berlaku telah cukup memadai untuk memberikan jaminan perlindungan HAM bagi tersangka/terdakwa tanpa menjadi beban berarti bagi aparat penegak hukum, sehingga mengganggu kemampuan penegakan hukum piḍana secara menyeluruh.

Aparat penegak hukum pidana terutama di tingkat pemeriksaan penyelidikan dan atau penyidikan seringkali melakukan pelanggaran batas kewenangan yang diberikan oleh hukum acara pidana, yang sebenarnya sekaligus juga merupakan pelanggaran HAM kepada tersangka/terdakwa. Reutgers yang pemah menülis buku mengenai Het Indlandsch Reglement (IR) pemah menuliskan laporan menǵenai bagaimana Kepala Desa yang menjadi kepanjangan tangan Polisi Kolonial, seringkali unjuk kemampuan bahwa mereka mampu secara cepat menyelesaikan penanganan perkara pidana yang terjadi di desanya, sering mempergunakan informan, saksi palsu, dan melakukan upaya paksa secara sewenangwenang. Meskipun hal itu diketahui, narnun dibiarkan saja oleh para kontrolir, asisten residen, dan bahkan residen sekalipun. ${ }^{3}$

Sesudah Indonesia merdeka, temyata aparat penegak hukum pidana masih "mewarisi" pola, model, atau cara yang sering dilakukan oleh petugas penegak hukum pidana di masa penjajahan. Besar kemungkinan kondisi tersebut merupakan konsekuensi logis dari masih dipakainya hukum acara pidana peninggalan Pemerintah Kolonial, yaitu Herziene Indlandsch Reglement (HIR), yang diberlakukan berdasarkan Undang-undang (UU) No.l/Drt./Tahun 1951.

Masih diberlakukannya HIR pada masa sesudah kemerdekaan telah menimbulkan rasa tidak puas, terutama dari kalangan ahli hukum dari kalangan perguruan tinggi dan para ahli hukum yang menjunjung tinggi HAM. Kondisi tersebut makin diperparah lagi pada waktu Pemerintah Orde Lama mengeluarkan

'Arief Setiawan. "Proses Peradilan Pidana di Indonesia dalam Perspektif Hak Asasi Manusia: Studi Khusus tentang Pelaksanaan Perlindungañ Hakk Asasi Manusia Bagi Tersangkadalam Proses Pemeriksaan Pendahuluan. Tesis. Jakarta. 1996. Tidak Diterbitkan.

${ }^{2} \mathrm{Hak}$ yuridis adalah perlindungan HAM bagi tersangka dan atau terdakwa, atau saksi yang telah secara khusus diformulasikan ke dalam hukum acara pidana positif.

${ }^{3}$ Mardjono Reksodiputro. 1994. Sistem Peradilan Pidana dalam Perspektif Hak Asasi Manusia. Jakarta: Lembaga Kriminologi Universitas Indonesia. HIm. 78, 91. 
UU No.19/Tahun 1964 LN 1964 No. 107 tentang Ketentuan-ketentuan Pokok Kekuasaan Kehakiman, di mana dalam Pasal 19 memberikan kewenangan kepada Presiden selaku:pihak eksekutif untuk ikut campur tangan dalam kehidupan pengadilan demi kepentingan revolusi. Hal ini tentu saja telah semakin menciptakan suasana yang tidak kondusif bagi dunia peradilan, sehingga menimbulkan reaksi dan keinginan untuk segera memperbaikinya.

Selama kurun waktu tujuh belas tahun (1963-1979) telah dilakukan empat kali seminar hukum nasional oleh L.PHN/BPHN bekerjasama dengan perguruan tinggi negeri ternama yang mempunyai fakultas hukum, seperti Universitas Indonesia, Universitas Gajah Mada, dan Universitas Diponegoro, yang membahas isu utama mengenai perlu negara Indonesia segera melakukan pembaharuan hukum (termasuk hukum acara pidana) yang lebih dijiwai semangat kemerdekaan dan HAM. Munculnya UU No.8 Tahun 1981 tentang Kitab Undang-undang Hukum Acara Pidana (KUHAP) nampaknya dapat dipandang sebagai satu tonggak penting dalam sejarah hukum acara pidana di Indonesia yang dijiwai semangat Rule of Law dan jaminan perlindungan HAM bagi tersangka/terdakwa tanpa melupakan kepentingan kelancaran pelaksanaan tugas bagi aparat penegak hukum pidana. Setidaktidaknya hal itu tergambar dari konsideran dan Penjelasan Umum KUHAP.

Narnun, apa yang terjadi sesudah KUHAP diberlakukan selama dua puluh tahun, temyata masih saja terdapat perbedaan pendapat antara para pengacara/advokat disatu pihak dengan aparat penegak hukum (polisi, jaksa penuntut umum, dan hakim) di pihak yang lain mengenai jaminan perlindungan HAM bagi tersangka/terdakwal terpidana dalam proses peradilan pidana. Pada urnumnya, kalangan advokat/pengacara masih belum puas dengan jaminan perlindungan HAM yang diberikan oleh KUHAP maupun yang telah dilaksanakan oleh aparat penegak hukum. Sementara, di pihak aparat penegak hukum sering berpendapat sebaliknya, yaitu bahwa KUHAP telah cukup memadai dalam memberikan jaminan HAM, demikian juga aparat penegak hukum juga merasa telah melaksanakan seluruh kewajibannya dalam memberikan jaminan HAM.

Adanya perbedaan pandangan mengenai jaminan HAM dalam hukum acara pidana dan pelaksanaan pemberian jaminan HAM berdasarkan hukum acara pidana yang terjadi di Indonesia merupakan suatu realita yang tidak dapat dibantah lagi sehingga perlu mendapatkan porsi perhatian, setidak-tidaknya untuk menjelaskan dua hal berikut:

1. Betulkah telah terjadi perbedaan cara memandang terhadap masalah pemberian hak-hak yuridis serta pelaksanaan pemberian hak yuridis tersangka dan terdakwa dalam sistem peradilan pidana di Indonesia antara pihak tersangka/terdakwa atau.Advokat/ Pengacara di satu sisi dengan aparat penegak hukum pidana (Polisi, Jaksa Penuntut Urnum, dan Hakim) pada sisi yang lain.

2. Betulkah kedudukan dan peranan masingmasing pihak yang terlibat dalam sistem peradilan pidana merupakan variabel yang menentukan terhadap persepsi, sikap, penilaian, dan pemberian makna 
(meaning) terhadap masalah jaminan hak yuridis dan pelaksanaan pemberian jaminan hak yuridis tersangka/terdakwa dalam sistem peradilan pidana?

Dengan mendasarkan pada pengamatan terhadap pelaksanaan KUHAP dari perspektif HAM dan sistem peradilan pidana (SPP) secara. komperhensif dan terpadu ada kalangan lembaga swadaya masyarakat (LSM) seperti Lembaga Bantuan Hukum (LBH) dari Yayasan Lembaga Bantuan Hukum Indonesia (YLBHI) yang bahkan telah merancang sendiri draft akademik usulan perubahan KUHAP. Usulan perlunya segera merubah KUHAP agar lebih berwawasan perlindungan HAM tersebut tentunya baik-baik saja sepanjang hal itu dilakukan dengan memperhatikan aspek keseimbangan kepentingan dari para pihak yang terlibat dalam SPP. Secara doktrinal hukum acara pidana yang baik harus memperhatikan (dalam arti mengakomodasi) semua kepentingan para pihak yang terlibat secara proporsional.

Pembaharuan hukum yang selama ini dilakukan seringkali bersifat top down, dari Pemerintah dan Dewan Perwakilan Rakyat (DPR) yang dalam beberapa hal tertentu juga melibatkan kalangan akademisi dan praktisi, narnun sifat top down-nya masih nampak dominan. Dengan kenyataan seperti ini hendaknya sebelum dilakukan pembaharuan KUHAP yang berwawasan HAM setidaktidaknya diperlukan suatu studi untuk melihat bagaimana sebenarnya persepsi para pihak yang terlibat dalam SPP/PPP mengenai jaminan HAM dan pelaksanaan jaminan HAM tersebut dalam SPP/PPP. Untuk melakukan studi mengenai hal tersebut di atas, dapat dilakukan dengan mempergunakan teori konstruksionisme yang dikenal dalam ilmu sosial.

Ada beberapa alasan mengapa teori tersebut relevan dipergunakan untuk menganalisis masalah tersebut yaitu: Pertama, dari aspek sosial teori tersebut dapat dipakai untuk menjelaskan pemahaman 'individual dan pemaknaan intersubjektif serta motif-motif tindakan manusia yang menurut teori tersebut dianggap sebagai agen yang berkompeten dan komunikatif menciptakan dan mongkonstruksi dunia sosial. Kedua, dan aspek hukum yang dilihat dalam perspektif sosial, bahwa hukum tidak selalu dalam keadaan "orderly" karena hukum tergantung kepada siapa (para pihak) yang memakai hukum tersebut. Sebagaimana pemah dikernukakan oleh hakim terkenal Oliver W. Holmes: "The live of the law has not been logic but experience", demikian juga menurut Sanford bahwa hukum ditentukan para pihak, dan hal itu tergantung dari posisi masingmasing di mana mereka berada, ketika mereka membaca hukum. ${ }^{4}$

\section{Teori Konstruksionisme}

Apabila masalah perbedaan pandangan mengenai masalah persepsi jaminan HAM dalam SPP dan pelaksaan jaminan HAM tersebut dilihat dari perspektif yuridis normatif

${ }^{4}$ Sartjipto Rahardjo. Materi Kuliah. Pada Program Doktor Ilmu Hukum Universitas Diponegoro. 7 Maret 2002. 
dogmatis, yaitu semata-mata hanya berdasarkan KUHAP beserta peraturan pelaksana dan peraturan lainnya yang terkait seperti UU Pokok Kekuasan Kehakiman, Kepolisian, Kejaksaan, Peradilan Urnum, dan Mahkamah Agung, tentunya tidak akan memperoleh penjelasan atau jawabanjawaban atas beberapa pertanyaan yang diajukan di atas. Dari segi yuridis normatif dogmatis, baik kalangan advokat/pengacara dan kalangan penegak hukum lainnya sernuanya mendasarkan alasannya berdasarkan ketentuan hukum yang sama, narnun mengapa muncul pandangan yang berbeda mengenai objek yang sama?

$\mathrm{Hal}$ ini tentu mengherankan kalangan penganut legal positivism yang berpandangan bahwa hukum itu netral hingga pemberlakuannya tidak akan dipengaruhi oleh para pihak yang terlibat dalam proses penerapan hukum itu. Bagi kalangan ilmuwan hukum yang mempergunakan perspektif non hukum (ilmu sosial, khususnya sosiologi) untuk melihat hukum dan kehidupan hukum, tentu saja tidak akan bersikap heran, karena bagi mereka hukum sebenarnya.tidaklah netral. Hukum itu penuh dengan muatan nilai, dan para pihak yang terlibat dalam pelaksanaan hukum pun juga mempunyai muatan-muatan nilai masing-masing yang tentunya akan mempengaruhi cara pandang dan penilaian mereka mengenai hukum dan pelaksanaannya. Dari perspektif sosial, muatan hukum sebenarnya tidak hanya peraturan (rules), tetapi meliputi juga perilaku (behavior), dan struktur sosial (social structure).$^{5}$

Menurnt Black ${ }^{6}$ disebutkan bahwa dalam studi hukum yang memakai pendekatan jurisprudential model, maka fokus perhatian pada hukum sebagai objek studi adalah peraturan yang bersifat pasti, dengan ruang lingkup berlakunya yang universal, dan proses berjalannya hukum pun juga dipandang demikian pasti sesuai dengan logika yang sudah ditetapkan sebelumnya. Model studi hukum seperti ini nampaknya memang dimaksudkan untuk suatu kepentingan praktis untuk suatu tujuan membuat keputusan. Model ini mengukur suatu gejala atau peristiwa dengan aturan (rules) melalui proses logika tertentu seperti penafsiran hukum, penghalusan hukum, ataupun konstruksi hukum.

Berbeda dengan studi hukum yang mempergunakan jurisprudential model, yang menurut Alan Hunt akarnya memang dari jurisprudence, maka sociological model yang, akarnya memang dari sosiologi, menurut Black akan memandang hukum bukan sebagai suatu kepasfian. Apa yang sudah ditetapkan oleh hukum masih dianggap perkiraanperkiraan (asurnsi atau hipotesis). Model pendekatan ini sangat memperhatikan masalah hukum dari segi struktur sosial dan perilaku masyarakat. Dua variabel tersebut merupakan kunci penting untuk melakukan studi hukum dalam perspektif sosial.

Untuk memahami karakter pokok yang membedakan kedua jenis model ini dapat dilihat dari figure di bawah ini:

\section{s/bid.}

${ }^{6}$ Donald Black. Tt. Sociological Justice: Introduction and the Boundaries of Legal Sociology. Foto Copy. Tp. 
Figure: Two Model of Law

\begin{tabular}{|c|c|c|c|}
\hline No. & Aspect & Jurisprudential Model & - Sociological Model \\
\hline 1. & Focus & Rules & Social structure \\
\hline 2. & Process & Logic & Behavior \\
\hline 3. & Scope & Universal & Variable \\
\hline 4. & Perspective & Participant & Observer \\
\hline 5. & Purpose & Practical & - $\quad$ Scientific \\
\hline 6. & Goal & Decision & $\therefore$ Explanation \\
\hline
\end{tabular}

Secara umum terdapat empat tipe teori dalam sösiologi, yang secara skematis" digambarkan Waters sebagai berikut : ${ }^{7}$

\section{The Types of Sociological Theorizing Nature of constitutive elements}

Subjective Objective

Term of Individualistic

Explanation Holistic Functionalism
Constructionism. Utilitarianism

Critical Structuralism
Untuk -keperluan analisis terhadap masalah yang diajukan di atas, hendaknya dipergunakan teori. konstruksionisme (constructionism theory) yang dikenal dalam teori sosial. Posisi teori konstruksionisme dalam teori sosial dapat dilihat dalam figur di atas. Dengan mempergunakan teori ini diharapkan dapat diternukan pemahaman in- dividual dan. pemaknaan-pemaknaan intersubjektif dan motif-motif. di mana dalam hal ini manusia dianggap, sebagai agen yang kompeten dan komunikatif yang secara aktif menciptakan atau mengkonstruksi dunia sosial. ${ }^{8}$ Dalam konteks penulisan yang akan dijadikan sebagai objek kajian adalah pàra pihak yang terlibat dalam sistem peradilan

${ }^{7}$ Malcom Waters. 1994. Modern Sociological Theory. London: Sage Publications Ltd. HIm. $6.4 \%$

8/bid. HIm. 5-6. 
pidana, yaitu bagaimana mereka sebagai individu yang mempunyai kedudukan (status) dan peranan (apa yang bisa dilakukan seseorang sesuai dengan statusnya) dalam sistem peradilan pidana mengkonstruksi terhadap tindakan-tindakan dan realitas yang dihadapinya untuk memberikan pemaknaan terhadap hal itu.

Teori konstruksionisme pada masa klasik dapat dilihat dari dua kemungkinan, yaitu: Pertama, mulai dari teori Weber, sedang pada masa modem muncul dalam teori symbolic interactionism (interaksionisme), dan pada masa kini (postmodernism) ada pada teori structuration (strukturasi) dari Anthony Gidden; atau Kedua, mulai dari teori klasiknya Simmel, yang masa modem muncul dalam teori fenomenologi atau etnometodologi, sedang di masa kini (posmodemisme) muncul dalam teori strukturasinya Anthony Gidden. Fondasi utama teori konstruksionisme baik yang dimulai dari teori Weber maupun Simmel sebenarnya adalah konsep mengenai agency (agensi). ${ }^{9}$ Menurut teori konstruksionisme, manusia selalu menjadi agen dalam mengkonstruksi realitas sosial yang aktif. Cara mereka bertindak tergantung pada bagaimana mereka memahami atau memberi arti pada tingkah laku mereka. Jadi dalam hal ini para ahli sosiologi harus menginterpretasikan, yaitu memberi pemaknaan-pemaknaan yang ditetapkan 'oleh partisipan. ${ }^{10}$ llustrasi sederhana di bawah ini akan dipakai untuk menjelaskan mengenai hal itu.
Apa makna wama lampu pada lampu pengatur lalu lintas misalnya wama "lampu kuning" yang menyala sesudah "lampu hijau" dan bagaimana sikap dan tindakan mereka sesudah mengetahui hal itu? jika hal itu ditanyakan pada seseorang yang berprofesi sebagai sopir bus kota, mungkin ia akan memberikan makna bahwa lampu kuning berarti para pengemudi harus mempercepat laju kendaraannya supaya lampu merah tidak keburu menyala. Jika ia mengalami hal itu, ia akan melakukan tindakan sesuai dengan makna yang ia berikan pada wama lampu tersebut. Narnun, jika hal itu ditanyakan kepada seseorang yang berprofesi sebagai polisi, jawabannya mungkin akan bertolak belakang, bahwa wama lampu kuning tersebut berarti semua pengemudi harus mengurangi kecepatannya untuk bersiap-siap berhenti sebelum lampu wama merah menyala agar terhindar dari kecelakaan lalu lintas. Jika ia mengalami hal itu, ia akan bertindak sesuai dengan makna yang ia berikan pada wama lampu tersebut.

Seorang tersangka yang sedang ditahan oleh Penyidik dari kepolisian karena disangka melakukan kejahatan, selama ditahan ia tidak diperbolehkan memakai celana panjang, baju panjang dan selimut, sementara pada saat itu sedang musim dingin. Jika hal ini ditanyakan kepada seorang tersangka atau Penasehat Hukumnya, mungkin mereka akan memberikan tanggapan bahwa Penyidik telah melakukan perbuatan yang tidak manusiawi (melanggar HAM) terhadap Tersangka.

9/bid. Him. 7-8.

10/bid. 
Karena pada saat musim dingin tidak diberi alat-alat penghangat tubuh, hal itu bisa memicu seseorang menjadi mudah sakit. Seharusnya seorang tahanan tetap diberikan perlakuan yang manusiawi. Narnun demikian, jika hal itu ditanyakan kepada petugas yang menahan Tersangka, la mungkin akan memberikan tanggapan berbeda, bahwa ia berkewajiban menjaga keamanan dan keselamatan para tahanan, jika di dalam sel tahanan terdapat baju dan celana panjang serta selimut hal itu bisa dimanfaatkan tahanan tersebut untuk alat bantu melarikan diri atau mungkin untuk bunuh diri dengan cara menggantung diri di sel. Mengingat resiko tersebut petugas memilih untuk tidak mengijinkan tahanan memakai baju dan celana panjang serta selimut.

llustrasi yang lain misalnya, ketika Tommy Soeharto ditangkap oleh Polda Metro Jaya, kemudian sesampainya di markas kepolisian ia disambut dengan pelukan oleh Kapolda Soefjan Jacob dan diberi ucapan selamat datang. Contoh gambaran yang lain misalnya ketika petugas penyidik yang sedang memeriksa tersangka selalu memberikan senyuman atau mungkin suatu ketika ia selalu cemberut, atau bahkan suatu kali ia membentak. Apa makna pelukan dan ucapan yang diberikan kepada Tommy yang pada saat itu dianggap sebagai buronan tersangka kejahatan? Demikian juga apa makna dari senyuman, muka cemberut atau bentakan oleh penyidik kepada tersangka?

\section{Konsep Agensi}

Jawaban-jawaban atas pertanyaan atau masalah yang diberikan kepada seseorang dalam beberapa ilustrasi contoh kasus di atas, mengandung alasan-alasan mengapa seseorang melakukan atau tidak melakukan suatu perbuatan, juga mengapa seseorang berpendapat tertentu mengenai suatu hal, sedang pihak lain berpendapat berbeda padahal masalah yang dibahas adalah sama. Dalam teori konstruksionisme, jawaban dan alasan mengenai tindakan tersebut sebenarnya telah memasuki pengertian mengenai konsep agensi.

Agensi adalah suatu gagasan yang menjelaskan bahwa seseorang menetapkan tujuan untuk mereka sendiri dan bertindak berdasarkan tujuan itu dengan sengaja. Dalam melakukan tindakan yang berdasarkan atas tujuan yang telah ditetapkan tersebut mereka memberikan pemaknaan terhadap tindakan atau perilaku mereka tersebut. Tindakan mereka tersebut menjadi masuk akal bagi mereka, dan ketika mereka menjelaskan alasan-alasan dan perhitungan mereka, perilaku mereka dapat juga menjadi masuk akal untuk orang lain. ${ }^{11}$

Dalam konsep agensi, individu-individu bukanlah produk atau bahkan korban dunia sosial, karena individu-individu adalah subjek yang berfikir, merasakan, dan bertindak menciptakan dunia di sekeliling mereka. Mereka bisa melakukan hal itu dengan sengaja ataupun tidak. Hal yang penting dalam hal ini adalah bahwa mereka memberikan

"1/bid. HIm. 15. 
makna pada perilaku mereka sendiri dan orang lain. Secara ringkas karakteristik utama teori ini yang dipakai sebagai alasan utamamengapa teori ini dipakai sebagai alat analisis terhadap alasan utama mengapa teori ini dipakai sebagai alat analisis terhadap masalah yang dikernukakan adalah: ${ }^{12}$

1. Manusia diperlakukan sebagai subjek yang pandai dan kreatif, terutama untuk menkontrol kondisi-kondisi yang mempengaruhi kehidupan sosial mereka.

2. Manusia melengkapi perilaku mereka dengan makna. Karena itu tugas sosiologi adalah menyelidiki perilaku oleh karena itu sosiologi harus dapat menjadi disiplin ilmu yang "hermeneutic".

3. Perilaku manusia dimotivasi oleh pemaknaan yang diberikan tindakan yang berkaitan dengan cara di mana mental individu memproyeksikan tindakan melalui waktu untuk mencapai tujuan. Motif-motif tersebut dapat diakses ahli sosiologi dengan memakai perhitungan atau alasan verbal untuk perilaku.

4. Substansi dunia sosial adalah interaksi manusia, suatu proses konstan mengenai negosiasi makna antarsubjek dengan mempergunakan kata-kata, gerakan, dan simbol-simbol lain.

5. Pola-pola yang teratur muncul dalam interaksi manusia sehingga tidak semua aspek makna harus dinegosiasi ulang. Pola-pola yang muncul ini merupakan susunan kehidupan sosial yang berskala besar yang dianggap pasti.
6. Tekanan dalam teori agensi adalah bagaimana memberikan gambaran dan penjelasan mengenai pengalaman sosial yang baru dan terjadi setiap hari, seringkali dari sudut pandang individu atau tipe individu tertentu dari pada membuat teori susunan struktural berskala besar.

\section{Simpulan}

Dalam perspektif teori konstruksionisme, masing-masing pihak yang terlibat dalam proses peradilan pidana, sesuai dengan kedudukan dan peranan masing-masing dalam proses peradilan pidana tersebut akan membuat gagasan untuk menetapkan tujuan mereka sendiri, dan bertindak sesuai dengan tujuan yang ditetapkannya itu dengan sengaja. Dalam melakukan tindakan tersebut mereka lalu memberikan pemaknaan (meaning) terhadap tindakan atau tingkah laku mereka, 'dan juga akan memberikan alasan mengenai dilakukannya tindakan tersebut.

Dengan mendasarkan pada simpulan hipotetik yang pertama, maka akan terjadi perbédaan persepsi, sikap, penilaian, dan pemberian makna (meaning) terhadap masalah pemberian hak-hak yuridis serta pelaksanaan pemberian hak yuridis tersangka dan terdakwa dalam sistem peradilan pidana di Indonesia antara pihak tersangka/terdakwa atau Advokat/Pengacara di satu sisi dengan aparat penegak hukum pidana (Polisi, Jaksa Penuntut Umum, dan Hakim) pada sisi yang lain. Perbedaan kedudukan dan peranan masing-masing pihak dalam proses peradilan

'2lbid. 
pidana akan menjadi variabel yang menentukan terhadap adanya perbedaan persepsi, sikap, penilaian, dan pemberian makna (meaning) terhadap masalah jaminan hak yuridis dan pelaksanaan pemberian jaminan hak yuridis Tersangka/Terdakwa dalam sistem peradilan pidana? $\mathrm{a}$

\section{Daftar Pustaka}

Black, Donald. Tt. Sociological Justice: Introduction and the Boundaries of Legal Sociology. Foto Copy. Tp.

Rahardjo, Sartjipto. Materi Kuliah. Pada Program Doktor Ilmu Hukum. Universitas Diponegoro. 7 Maret 2002.
Reksodiputro, Mardjono. 1994. Sistem Peradilan Pidana dalam Perspektif Hak Asasi Manusia. Jakarta: Lembaga Kriminologi Universitas Indonesia:

Setiawan, Arief. "Proses Peradilan Pidana di indonesia dalam Perspektif Hak Asasi Manusia: Studi Khusus tentang Pelaksanaan Perlindungan Hak Asasi Manusia Bagi Tersangka dalam Proses Pemeriksaan Pendahuluan. Tesis. Jakarta. 1996. Tidak Diterbitkan.

Waters, Malcom. 1994. Modern Sociological Theory. London: Sage Publications Ltd.

(1) จ จ 